Article

\title{
Tropical Wood Dusts-Granulometry, Morfology and Ignition Temperature
}

\author{
Miroslava Vandličková, Iveta Marková * (1), Linda Makovická Osvaldová(i), \\ Stanislava Gašpercová, Jozef Svetlík $@$ and Jozef Vraniak
}

Department of Fire Engineering, Faculty of Security Engineering, University of Žilina, Univerzitná 8215/1, 01026 Žilina, Slovakia; miroslava.vandlickova@fbi.uniza.sk (M.V.); linda.makovicka@fbi.uniza.sk (L.M.O.); stanislava.gaspercova@fbi.uniza.sk (S.G.); jozef.svetlik@fbi.uniza.sk (J.S.); vraniak.jojo@gmail.com (J.V.)

* Correspondence: iveta.markova@fbi.uniza.sk; Tel.: +421-41-513-6799

Received: 26 September 2020; Accepted: 26 October 2020; Published: 28 October 2020

\begin{abstract}
The article considers the granulometric analysis of selected samples of tropical wood dust from cumaru (Dipteryx odorata), padauk (Pterocarpus soyauxii), ebony (Diospyros crassiflora), and marblewood (Marmaroxylon racemosum) using a Makita 9556CR $1400 \mathrm{~W}$ grinder and K36 sandpaper, for the purpose of selecting the percentages of the various fractions $(<63 ; 63 ; 71 ; 200$; $315 ; 500 \mu \mathrm{m}$ ) of wood dust samples. Tropical wood dust samples were made using a hand orbital sander Makita 9556CR $1400 \mathrm{~W}$, and sized using the automatic mesh vibratory sieve machine Retsch AS 200 control. Most dust particles (between 50-79\%) from all wood samples were under $100 \mu \mathrm{m}$ in size. This higher percentage is associated with the risk of inhaling the dust, causing damage to the respiratory system, and the risk of a dust-air explosive mixture. Results of granulometric fractions contribution of tropical woods sanding dust were similar. Ignition temperature was changed by particle sizes, and decreased with a decrease in particle sizes. We found that marblewood has the highest minimum ignition temperature $\left(400-420^{\circ} \mathrm{C}\right)$, and padauk has the lowest $\left(370-390^{\circ} \mathrm{C}\right)$.
\end{abstract}

Keywords: tropical wood dust; granulometric sieve analysis; morphology shape of particles; temperature of ignition

\section{Introduction}

During wood processing, dust is created as a by-product [1-7], and plays a negative role in assessing the risk of fire [8] or explosion [9-14]. Wood fust also poses a significant risk to the health of the human body $[15,16]$.

The damaging effect of wood dust is determined according to the particle size. Larger size fractions tend to settle $[17,18]$, whereas if the particle is smaller (such as below $100 \mu \mathrm{m}$ ), the dust becomes airborne. In the production process, dust is formed that contain particles of various sizes [5]. A granulometric analysis determines the degree of crushing of the base material-which is one of the characteristic abilities of form airborne dust mixture [8].

Reinprecht et al. [19] classify tropical woods as wood that demonstrates significant resistance to biological agents and machine wear and tear, together with solid dimensional stability and pretty aesthetics. These types of wood are commonly used for exterior constructions, tiles, garden furniture, or special plywood [20-22]. The expansion of their processing brings the creation of their wood dust.

Reinprecht et al. [23] made a detail analysis of seven types of tropical woods: Kusia (Nauclea diderichii Merill), bangkirai (Shorea obtusa Wall; Sh. spp.), massaranduba (Manilkara bidentata A. Chev.; M. spp.), jatobá (Hymenaea courbaril L.), ipé (Tebebuia serratifolia Nichols.; T. spp.), cumaru (Dipteryx odorata (Aubl.) Wild.)—996 $\mathrm{kg} \cdot \mathrm{m}^{-3}$, and cumaru rosa (Dipteryx magnifica (Ducke))-1014 kg. $\mathrm{m}^{-3}$. 
The samples were studies during different weather conditions, using a 36-mount in the exterior, and results showed the lowest lightening cumaru samples than others.

Tropical woods have natural durability [24]. There are resistant to decay fungi [19], insects, and dimensional changes. This is due to extractants that have a biocidal effect, such as coumarins, flavonoids, and tannins, and a hydrophobic effect, such as fats, oils, and waxes [25,26]. Giraldo et al. [27] declare that morphology, together with differences in the inorganic constituents, significantly affects the combustion process of wood.

The major parameter to assess the risk of airborne dust ignition is ignition temperature. Ignition temperature is closely surveyed using standardized equipment [28], where the airborne tropical wood dust is loaded heat. The ignition temperature (SIT) is the lowest temperature at which, under the defined test conditions, ignition occurs by heating, without the presence of any additional flame source [29].

This study aims to examine and seek comparative similarities between the granulometric structure of wood sanding dust from cumaru (Dipteryx odorata), padouk (Pterocarpus soyauxii), ebony (Diospyros crassiflora), and marblewood (Marmaroxylon racemosum). The prepared tropical dust was analyzed for the purpose of identifying its morphological structure, and determining the given physical properties (average dust moisture and bulk density). We have focused on microfractions of tropical wood dust (size of particles $\leq 100 \mu \mathrm{m})$, and focused the minimum particle size $(<100 \mu \mathrm{m})$ required to cause ignition within airborne tropical dusts.

\section{Sample Materials and Methods}

\subsection{Samples-Tropical Woods}

Four samples of wood dust from foreign wood species were used for this study. Samples of tropical wood were selected while considering their use in the production of floor coverings, furniture, and interior decorative items (Table 1).

Table 1. Samples used in the experiment.

\begin{tabular}{|c|c|c|}
\hline Common Name ${ }^{1}$ & Scientific Name & Density $\left(\mathrm{kg} \cdot \mathrm{m}^{-3}\right)$ \\
\hline Cumaru & Dipteryx odorata & $1075.69 \pm 10.04$ \\
\hline Padauk & Pterocarpus soyauxii & $720.40 \pm 9.52$ \\
\hline Ebony & Diospyros crassiflora & $960.00 \pm 7.46$ \\
\hline Marblewood & Marmaroxylon racemosum & $1000.08 \pm 9.98$ \\
\hline
\end{tabular}

${ }^{1}$ Association Technique Internationale des Bois Tropicaux (ATIBT) in France.

Cumaru (Dipteryx odorata), together with abiurana (Pouteria guianensis), garapeira (Apuleia molaris), jequitiba (Cariniana sp.), Cedro (Cedrela odorata), angelim (Parkia pendula), angelim pedra (Hymenolobium excelsum), and cerejeira (Amburana acreana) belongs to the group of Amazonian woody plants [30,31]. The cumaru tree is very dense $\left(950-1000 \mathrm{~kg} \cdot \mathrm{m}^{-3}\right)$, tough, highly durable, and resistant to cracking when exposed to sunlight. Therefore, it is suitable for solid flooring, stair treads, furniture, and pool decks [32]. Moreover, it is frequently found in the states of Acre, Amapá, Amazonas, Pará, Rondônia, and Mato Grosso, as well as in neighboring countries like Guyana, Venezuela, Colombia, Bolivia, Peru, and Suriname [32].

Padauk (Pterocarpus soyauxii) is moderately heavy, strong, and stiff, with exceptional stability. It is a popular hardwood among hobbyist woodworkers because of its unique color and low cost. It has a unique reddish-orange coloration, and the wood is sometimes referred to by the name 'Vermillion'. It is commonly used in flooring, musical instruments/objects, tool handles, furniture, other small particular wood objects, and as veneer [33].

Ebony woods have many common names, such as Gabon Ebony, African Ebony, Nigerian Ebony, and Cameroon Ebony, and originate from the equator part of Western Africa. Heartwood $\left(955 \mathrm{~kg} \cdot \mathrm{m}^{-3}\right)$ is 
usually jet-black, with little to no variation or visible grain. Occasionally, dark brown or grayish-brown streaks may be present. Ebony's common uses small items, such as piano keys, musical instrument parts, pool cues, carvings, and other small specialty items [34]. Ebony is highly valued in the Hindu religion as a building material [35], base material [36,37], and for use in other items [38].

Marblewood, also known as Angelim Rajado, is distributed from Northeastern South America. This heartwood $\left(1005 \mathrm{~kg} \cdot \mathrm{m}^{-3}\right)$ is yellow to golden brown, with irregular brown, purple, or black streaks [39]. It is commonly used for tuned instruments/objects, flooring, carpentry, sliced veneer, and delicate furniture. Vivek et al. [40] introduced the possibility of using marblewood dust as a partial replacement for cement and sand in concrete.

The basic samples (Figure 1a) of cumaru $(152 \times 38 \times 38 \mathrm{~mm})$, Padouk $(131 \times 50 \times 20 \mathrm{~mm})$, ebony $(142 \times 36 \times 30 \mathrm{~mm})$, and marblewood $(120 \times 35 \times 35 \mathrm{~mm})$ were made by a private wood company in Žilina (Slovakia) by a wood cutting saw (CNC Panel Saw Machine, Shandong, China) (Table 1). The moisture content of the basic samples was approximately $8-10 \%$.

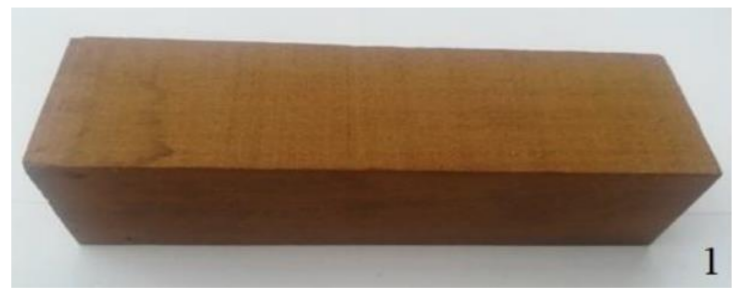

(a)

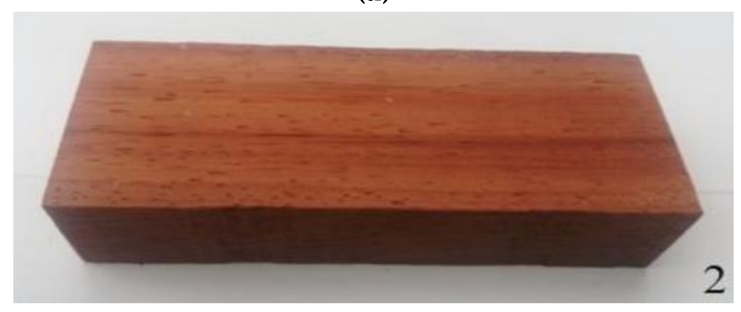

(a)

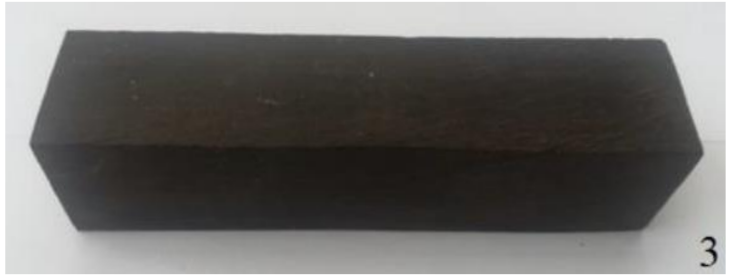

(a)

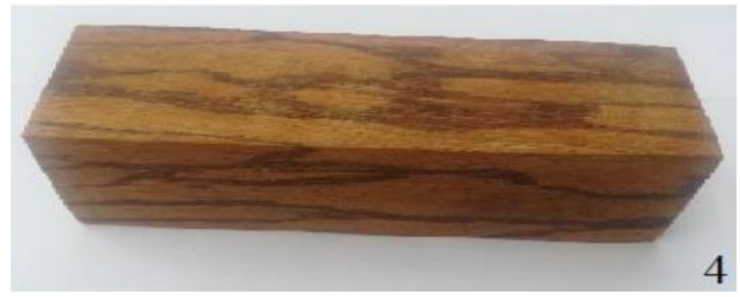

(a)

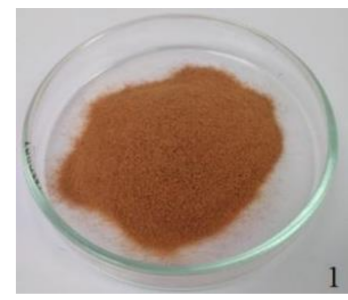

(b)

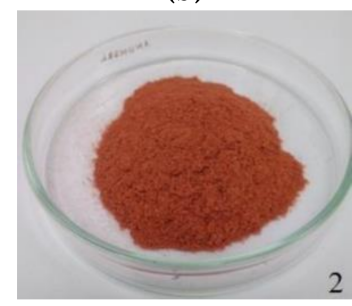

(b)

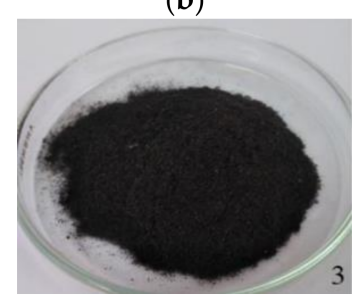

(b)

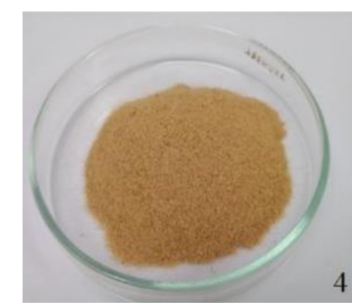

(b)

Figure 1. Experimental samples (a) in the form of plates; (b) in the form of prepared wood dust. The legend: (1) Cumaru (Dipteryx odorata); (2) African Parakeet (Pterocarpus soyauxii); (3) African Ebony (Diospyros crassiflora), and (4) Marblewood (Marmaroxylon racemosum).

\subsection{Preparation of Tropical Wood Dust Samples}

Technical equipment was used to prepare the homogeneous dust particles dust samples (Figure 1b) was Makita 9556CR 1400 W disc sander (Makita Numazu Corp., Branesti Ilfov, Romania) and K36 
sandpaper (Topex, Kinekus, Žilina, Slovakia). The grinding was carried out by the Experimental Laboratory at the Faculty of Security Engineering, University of Žilina (Slovakia). Tropical wood dust samples were prepared by a specialist in grinding. We aimed to ensure the grinding process was as close to reality as it is possible (in terms of pressure of the grinding surface of the component, grinding speed, and grinding direction (cross)). The prepared dust particles were amassed in the hopper with a hermetically sealed glass container, because it needed to stop the dust from absorbing any moisture. After the samples were ground three times, the hopper always was cleaned (in between samples). Overall, $300 \mathrm{~g}$ of dust was amassed from each board (three boards collection), and served for the granulometric examination. Detailed information about the preparation of dust samples can be found in Reference [29].

\subsection{Experimental Methods Utilised for Characteristics of Tropical Wood Dusts and Sieve Analysis}

The moisture of the tropical wood samples determined according to Reference [41], and the bulk density determined according to Reference [42], were selected characteristics of samples before sieve analysis (Table 2). The Retsch AS 200 sieve shaker vibration machine (Retsch AS 200 control, Retsch GmbH, Haan, Germany), using the seven fraction sizes (500, 315, 200, 100, 71, 63, and <63 $\mu \mathrm{m}$ ), was used for sieve analysis [43]. The sieves, in addition to the tropical wood dust, weighed $30 \mathrm{~g}$ (using laboratory scales with precision readings of $0.001 \mathrm{~g}$ ). The measurement procedures were conducted five times lasting $10 \mathrm{~min}$. The wood dust moisture testing was carried out according to Reference [44] -in a heated oven, at a temperature of $103 \pm 2{ }^{\circ} \mathrm{C}$ for $24 \mathrm{~h}$ (Table 2).

Table 2. Basic physical parameters of samples used in the experiment.

\begin{tabular}{ccccc}
\hline Tropical Dust Samples & Cumaru & Padauk & Ebony & Marblewood \\
\hline Average bulk density $(\mathrm{kg} \cdot \mathrm{m}-3)$ & $190.3 \pm 2.466$ & $167.3 \pm 4.355$ & $206.5 \pm 2.562$ & $187.9 \pm 8.535$ \\
Dust moisture $(\%)$ & $5.93 \pm 0.05$ & $5.34 \pm 0.08$ & $4.83 \pm 0.07$ & $7.34 \pm 0.1$ \\
\hline
\end{tabular}

\subsection{Experimental Methods for Shape of Wood Dust Particles}

The size, shape, and form of wood dust particles were studied by microscopic analysis, through a wide-field microscopy system (Nikon Eclipse Ni (Nikon Corp., Tokyo, Japan)) with a Nikon DS-Fi2 camera (Nikon Instruments Inc., Melville, NY, USA) [45]. This microscope possesses two c-mount camera ports, and an electric $X Y$ stage. This is the normal configuration for the bright field observation of this microscope.

A Nikon DS-Fi2 full-HD color camera (Nikon Instruments Inc., Melville, NY, USA), that uses one port, $2560 \times 1920$ pixels, was also used. This camera was used to establish the image by connecting it to the computer using a USB cable. Microscopic analyses of tropical wood dusts were performed using $100 \mu \mathrm{m}$ fraction precision.

The Institute of Research in Banská Bystrica, Slovakia, has a Nikon SMZ 1270 stereomicroscope (Nikon Corp., Beijing, China), which was used to analyze the shape of the dust particles. Equipment for the research of dust particles shape has a range with a 12.7:1 zoom head, and a magnification range of $0.63 \times$ to $8 \times$. The samples of the $500 \mu \mathrm{m}, 315 \mu \mathrm{m}, 200 \mu \mathrm{m}$, and $100 \mu \mathrm{m}$ fractions were measured in this stereomicroscope.

\subsection{Experimentation So as to Determine the Ignition Temperature Measurement of Airborne Dusts}

Specific test equipment (the detail of which can be found in Reference [29]) (VVUÚ, a.s., Ostrava, Czech Republic), with automatic weighing machines (Steinberg Systems, Łódź, Poland), an air compressor HL 100 ZU EINHELL (Einhell Corp., Landau an der Isar, Germany), and ALMEMO equipment (Ahlborn, Berlin, Germany) was used to the measurement of minimum ignition temperatures of airborne dusts (Figure 1a) according to the standard instructions [28]. The details of this are described in Vandličková et al. [29]. 


\section{Results and Discussion}

The average bulk density $\left(\mathrm{kg} \cdot \mathrm{m}^{-3}\right)$ and dust moisture (\%) were physical parameters connected with the preparation of dust samples (Table 2). Poorter et al. [46] consider of the density of tropical woods and the influence of climatic conditions on the growth and quality of wood mass. Tropical tree cumaro is considered a hardwood [47-50]. Soriano et al. [51] determined the density of cumoro in the range of $1060-1070 \mathrm{~kg} \cdot \mathrm{m}^{-3}$. Marblewood is also ranked among the hardwoods. Everything about working with marblewood revolves around its incredible hardness and density [52].

Ebony is different-it has a lower density $\left(960 \mathrm{~kg} \cdot \mathrm{m}^{-3}\right)$, and the highest value of average bulk density $\left(206.5 \mathrm{~kg} \cdot \mathrm{m}^{-3}\right)$.

King et al. [53] performed research on the growth of tropical trees in the Amazon and investigated their physical properties. The research samples included padauk trees, namely, Dipterocarpus cornutus Dyer. With a density of $(680 \pm 0.013) \mathrm{kg} \cdot \mathrm{m}^{-3}$ and Dipterocarpus globosus Vesque with a density of (690 \pm 0.017$) \mathrm{kg} \cdot \mathrm{m}^{-3}$.

\subsection{Results of Particle Sizes (Fractions) of Dust Samples}

Sanding dust particulates are minute and of complex composition, and are more hazardous to humans than the cutting dust particulates [54]. Wood dust particles (Figure 2) are normally generated in different sizes [12,55]. The percentages of particle sizes start from the size of $500 \mu \mathrm{m}$ (Table 3). Larger fractions occurred only at a minimal rate (at 1\%). Očkajová and Marková [56]; Očkajová et al. [5,57] presented the same result, which was presented for the chosen domestic tree samples.

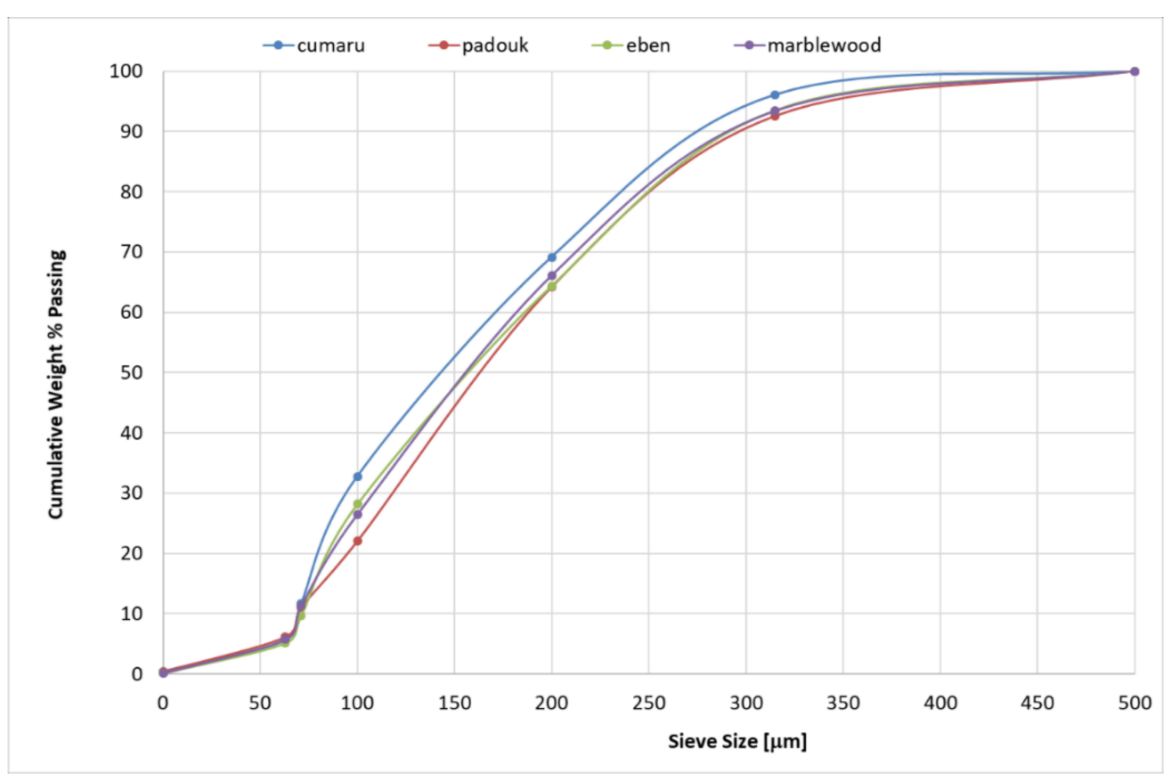

Figure 2. Continuous cumulative curve of cumaru, padauk, ebony, and marblewood dust.

Table 3. Determination of \% particle number fractions of the tropical wood dusts.

\begin{tabular}{ccccc}
\hline Fraction & \multicolumn{4}{c}{ \% Particle Number } \\
\hline Size & Cumaru & Padauk & Ebony & Marblewood \\
\hline 500 & $1.15 \pm 0.076$ & $1.55 \pm 0.115$ & $1.36 \pm 0.275$ & $1.26 \pm 0.244$ \\
315 & $2.78 \pm 0.745$ & $6.29 \pm 0.621$ & $5.15 \pm 0.537$ & $5.33 \pm 0.591$ \\
200 & $26.92 \pm 0.779$ & $28.37 \pm 0.547$ & $29.12 \pm 0.464$ & $27.31 \pm 0.462$ \\
100 & $36.37 \pm 1.2018$ & $42.14 \pm 1.049$ & $36.21 \pm 1.126$ & $39.61 \pm 0.367$ \\
71 & $21.14 \pm 0.875$ & $10.97 \pm 1.453$ & $18.56 \pm 0.180$ & $15.22 \pm 0.111$ \\
63 & $6.07 \pm 0.591$ & $4.92 \pm 0.312$ & $4.44 \pm 0.858$ & $5.5 \pm 0.383$ \\
$<63$ & $5.18 \pm 0.495$ & $5.81 \pm 0.399$ & $5.04 \pm 0.420$ & $5.64 \pm 0.612$ \\
\hline
\end{tabular}


The dust particles prepared from African Padauk had similar composition \% particle number, as well as spruce, oak, and beechwood [29].

Očkajová et al. [5] studied the size of fraction particles and share of wood dust particles (beech, oak, and spruce). Their solution formulated that the percentage share of dust particles is also very different, depending on the kind of this tree species. Our results showed similar size of particles (Table 3). Očkajová et al. [6] found a connection between the shares and densities of the wood dust. Their analyses regarding the wood dust in the sanding process showed that more dust is produced as the density of wood increases [54].

The results of dust sieving are presented by cumulative curves (Figure 2). The results are presented in passed weight percent of the individual fractions collected on a sieve with the appropriate mesh size. The results of the sieve analysis should be presented according to the appropriate standards [58,59]. Prepared continuous cumulative curves are presented in Figure 2 with complete mesh size.

\subsection{Shape Analysis of Dust Particles}

The characterization of wood dust samples from a morphological (Figures 3-6), and a dimensional point of view, yields information that can help epidemiologists and toxicologists to understand the causes of respiratory illnesses [60].
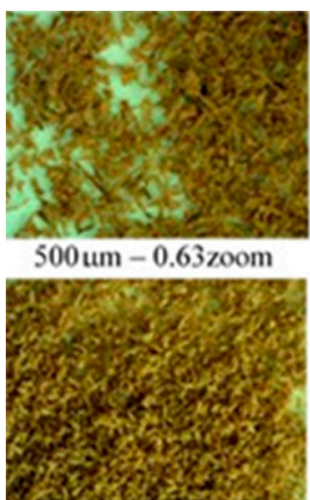

$315 \mathrm{um}-0.63 \mathrm{zoom}$

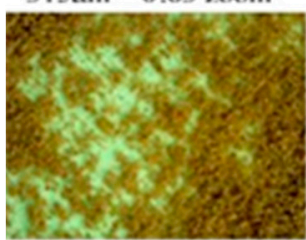

$200 \mathrm{um}-0.63$ zoom

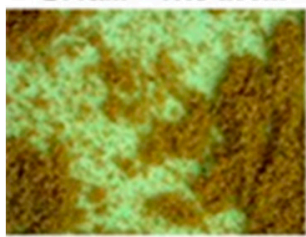

$100 \mathrm{um}-0.63 \mathrm{zoom}$

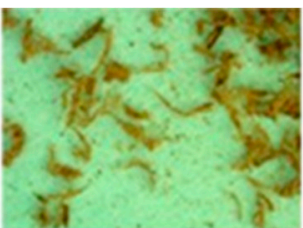

500 um - 1 zoom

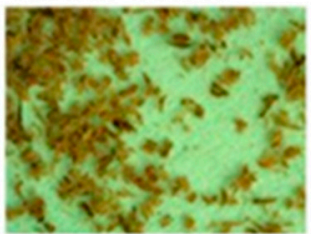

$315 \mathrm{um}-1$ zoom

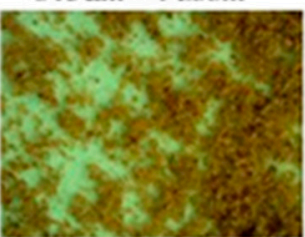

$200 u m-1$ zoom

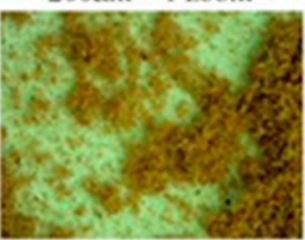

$100 \mathrm{um}-1$ zoom

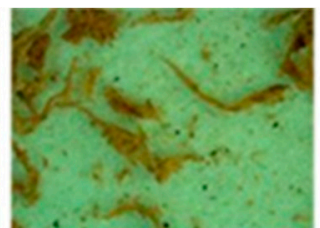

$500 u m-2$ zoom

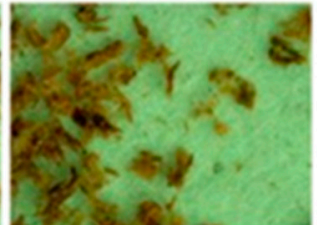

315 um - 2 zoom

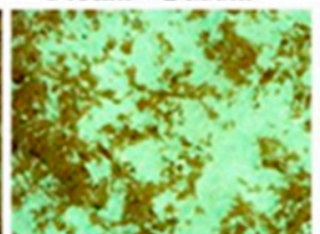

$200 u m-2$ zoom

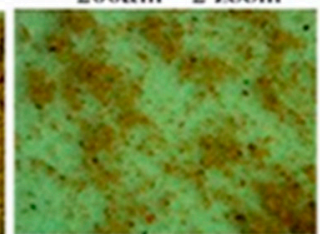

$100 \mathrm{um}-2$ zoom

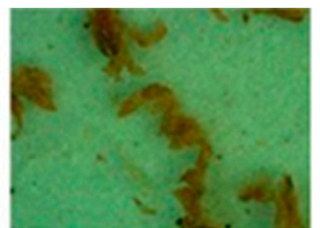

500 um -3 zoom

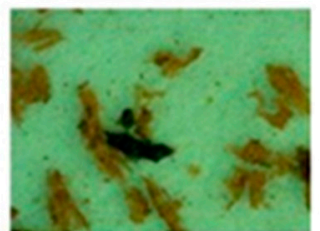

$315 \mathrm{um}-3$ zoom

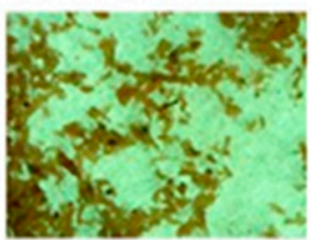

$200 u m-3$ zoom

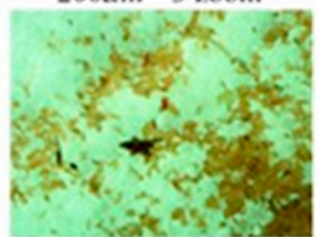

100 um -3 zoom

Figure 3. Cumaru dust particles and their shape. 


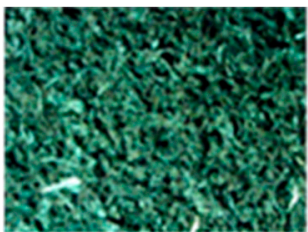

$500 u m-0.63 z o o m$

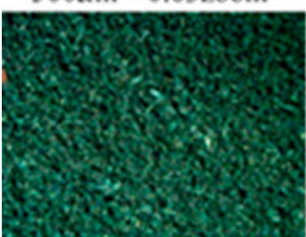

315 um -0.63 zoom

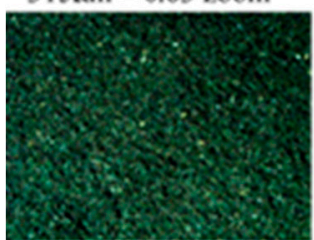

$200 u m-0.63$ zoom
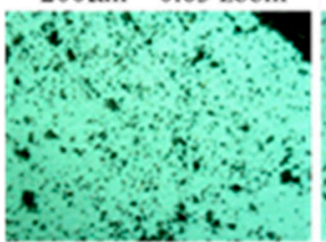

100 um -0.63 zoom

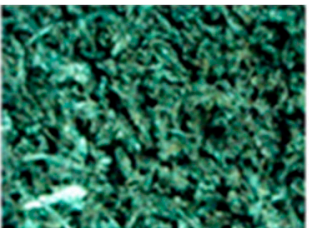

500 um -1 zoom

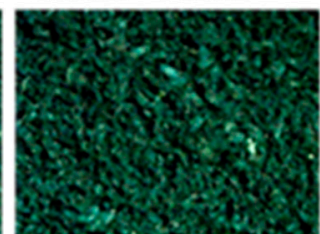

$315 \mathrm{um}-1$ zoom

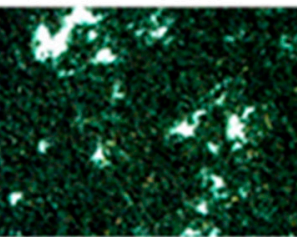

200 um - 1 zoom

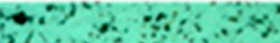

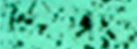
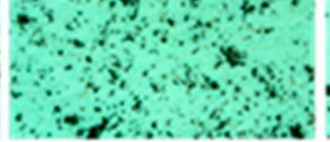

$100 \mathrm{um}-1$ zoom

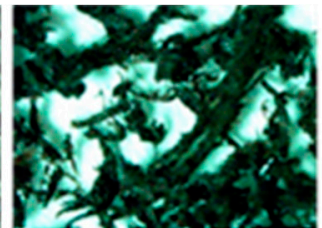

500 um - 2 zoom

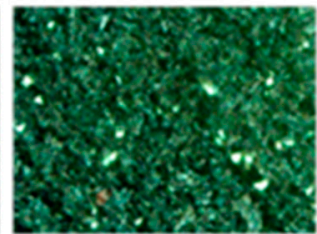

315 um - 2 zoom

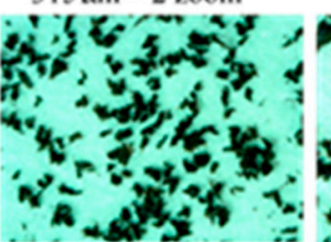

200um - 2 zoom

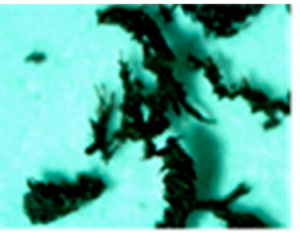

500 um - 3 zoom

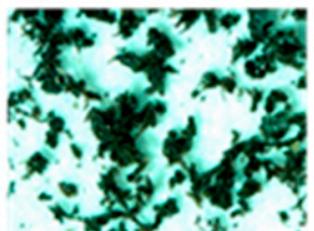

$315 \mathrm{um}-3 \mathrm{zoom}$

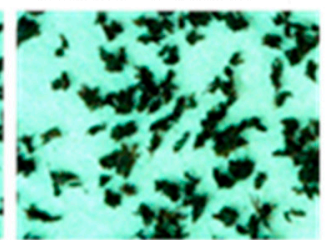

200um - 3 zoom

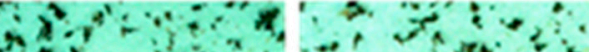

,

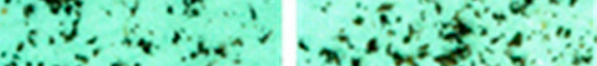

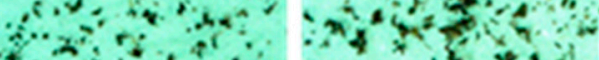
itis

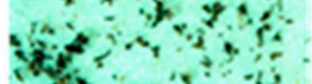

$100 \mathrm{um}-3 \mathrm{zoom}$

Figure 4. Ebony dust particles and their shape.
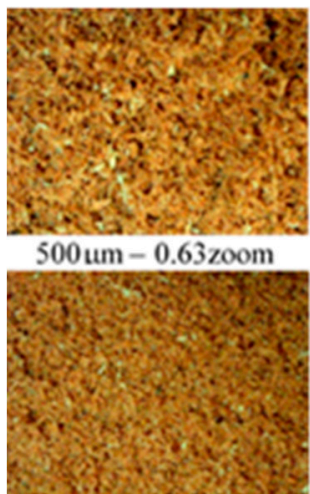

315 um -0.63 zoom

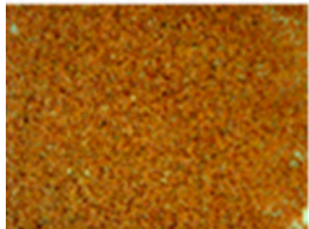

200 um - 0.63 zoom

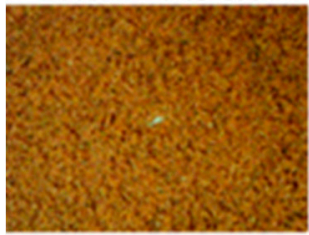

100 um -0.63 zoom

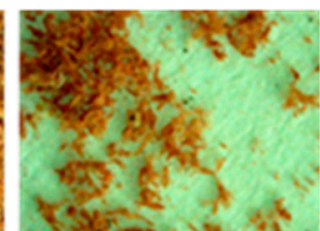

$500 \mathrm{um}-1 \mathrm{zoom}$

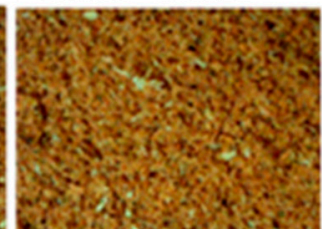

$315 \mathrm{um}-1 \mathrm{zoom}$

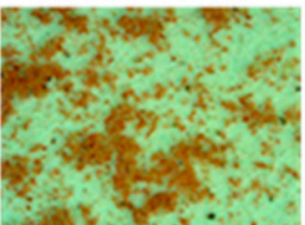

200um - 1 zoom

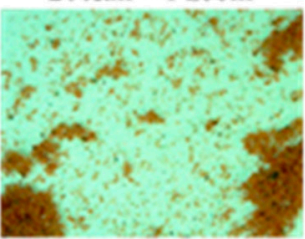

100 um - I zoom

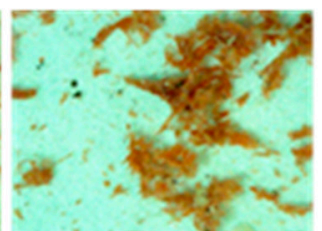

$500 \mathrm{um}-2$ zoom

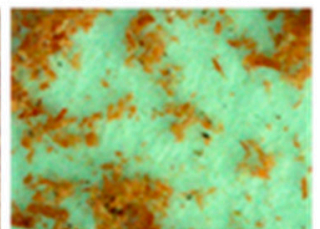

315 um - 2 zoom

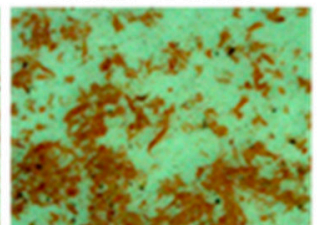

200um - 2 zoom

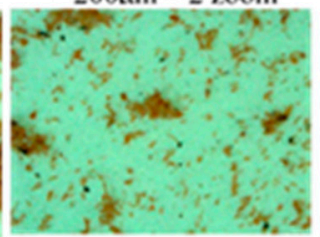

$100 \mathrm{um}-2 \mathrm{zoom}$

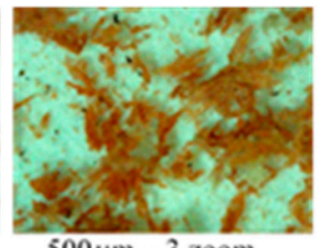

500 um - 3 zoom

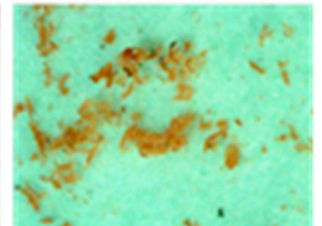

315 um -3 zoom

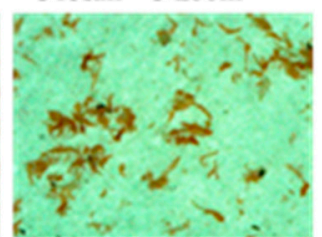

$200 u m$ - 3 zoom

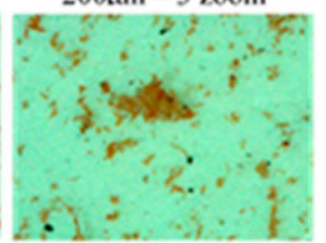

100 um -3 zoom

Figure 5. Padauk dust particles and their shape. 

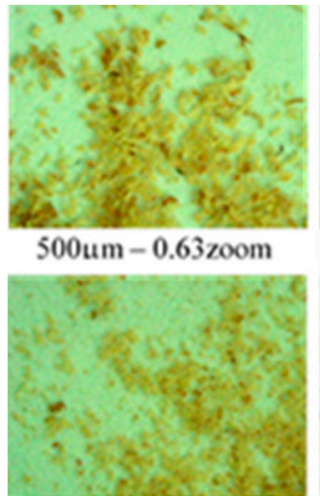

$315 \mathrm{um}-0.63 \mathrm{zoom}$
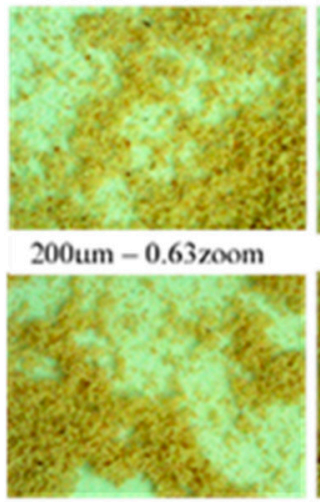

$100 \mathrm{um}-0.63 \mathrm{zoom}$

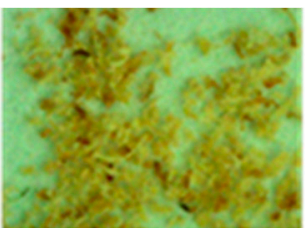

500 um - I zoom

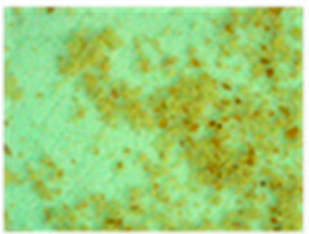

$315 u m-1$ zoom

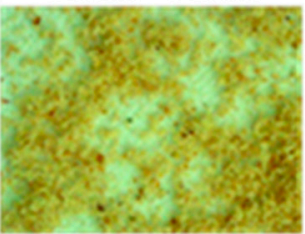

$315 \mathrm{um}-1$ 7oom

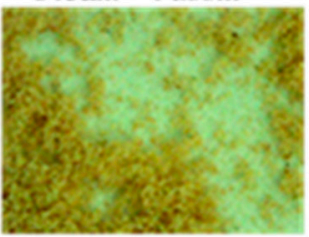

$100 u m$ - 1 zoom

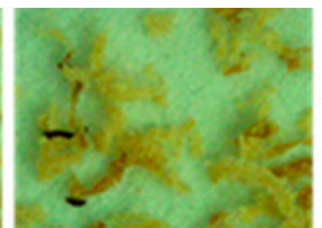

500um - 2 zoom

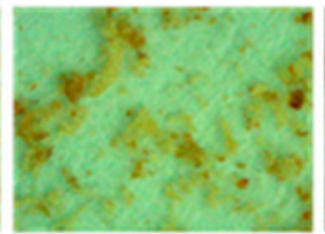

315 um - 2 zoom

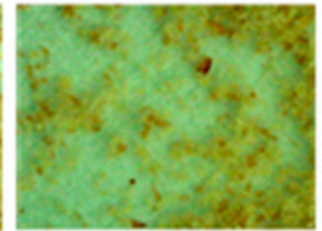

200um- 2 zoom

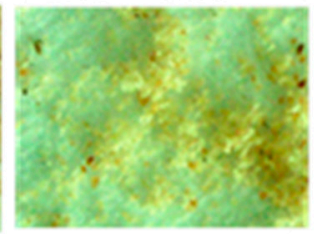

100 um - 2 zoom

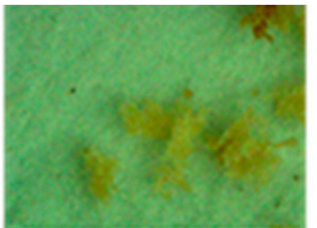

$500 u m-3$ zoom

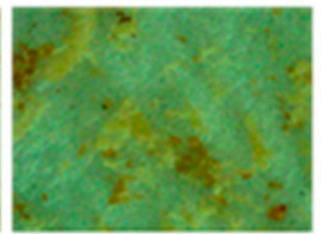

315 um - 3 zoom

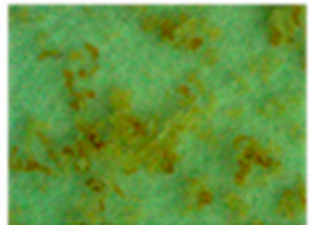

200um - 3 zoom

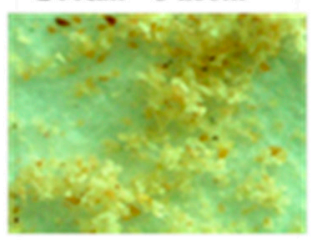

100 um - 3 zoom

Figure 6. Marblewood dust particles and their shape.

The particles in our sample show a range of shapes and sizes of particles [61]. The size $100 \mu \mathrm{m}$ is the boundary value of a particle size, where dust is expected to becomes airborne and is potentially explosive $[62,63]$. Within the basic range of size particles, dust can be classified as coarse (particle diameter of $>100 \mu \mathrm{m}$ ) or fine (particle diameter of $<100 \mu \mathrm{m}$ ) [64].

The anatomical structure is preserved in analyzed particles [65]. When magnified, the fractions of 500, 315, 200, and $100 \mu \mathrm{m}$ ( Figures 3-6) appeared differently-they had their own specific shapes. Figure 3 shows the fractions of cumaru, and Figure 6 fractions of marblewood.

Selected tropical woods produce dust particles within the whole spectrum. The differences in morphology are shown in Figures 3-6. Cumaru and marblewood are hardwoods, with a density of $1000 \mathrm{gm}-\mathrm{m}-3$, and it is possible to state the similarity of the formed particles. The relationship between the particle shape and the initiation temperature can be shown in marblewood dust, which has the highest ignition temperature. Ebony offers a limited or bounded particle shape, and its ignition temperature is lower.

\subsection{Microscopic Dust Analysis}

The particles of tropical dust samples (Figure 7) have the size of $<100 \mu \mathrm{m}$. From the safety and occupational hygiene perspective, particles below $100 \mu \mathrm{m}$ are the most dangerous in the working environment [2]. The scans clearly show that the fibers of the dust particles maintain their anatomical structure with the fibrous character of particles [66]. The two-dimensional pictures of particles can be used for determining the smallest particle sizes. 


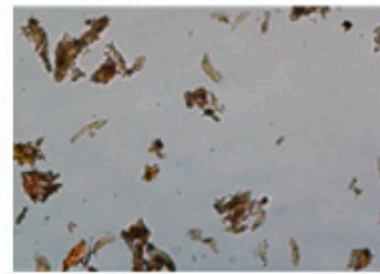

Cumaru- $10 x$

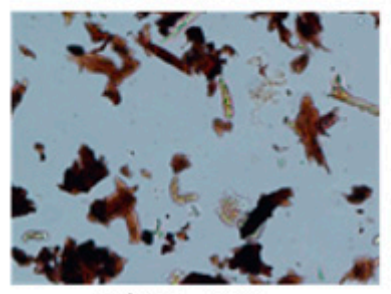

Eden-10x

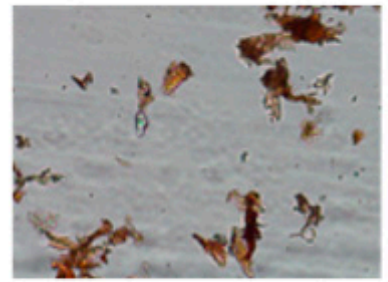

Padouk-10x

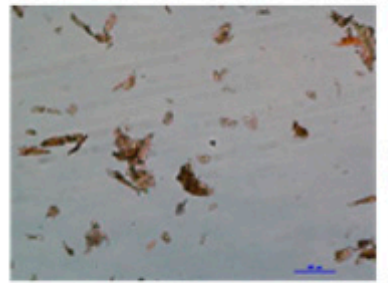

Marblewood-10x

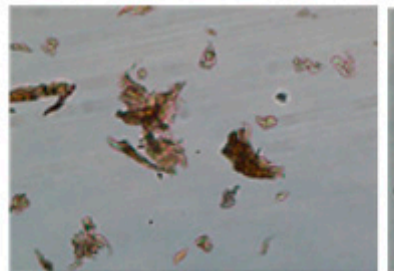

Cumaru-100x

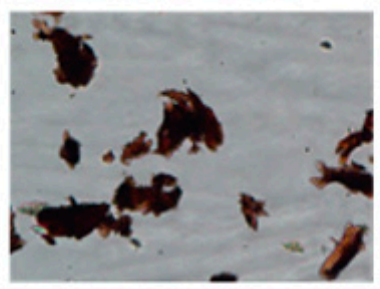

Eden-100x

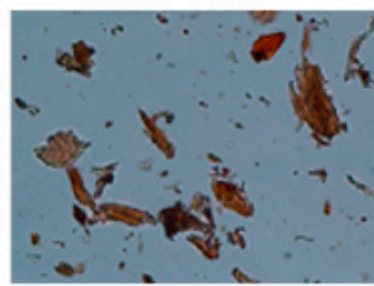

Padouk - $100 x$

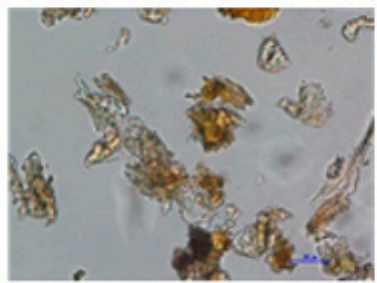

Marblewood-100x

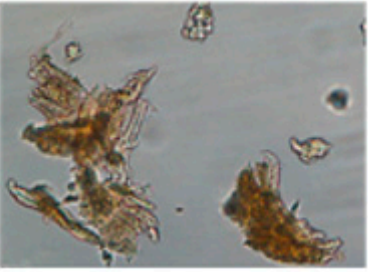

Cumaru- 200x

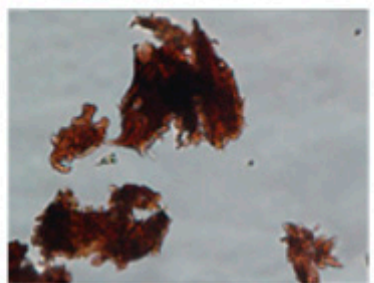

Eden-200x

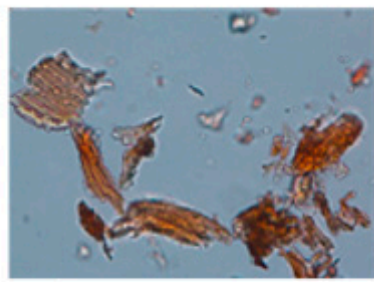

Padouk - 200x

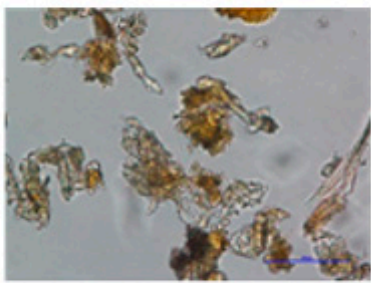

Marblewood-200x

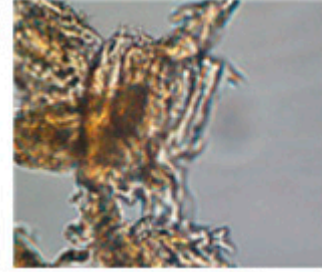

Cumaru $-400 x$

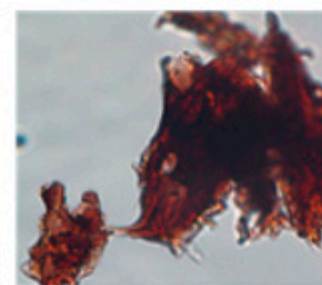

Eden - 400x

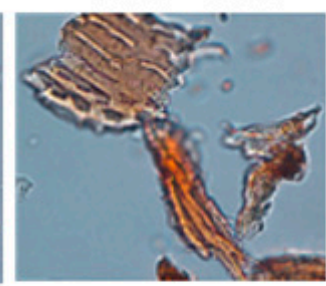

Padouk - 400x

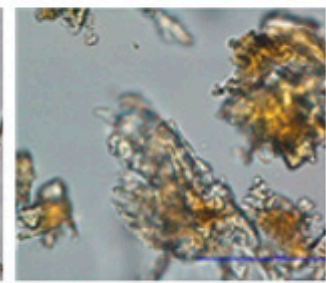

Marblewood-400:

Figure 7. Light microscopic images of tropical dust fibers with 100×, 200×, and 400× zoom. Legend:

Blue line presents a size of 100 microns $(\mu \mathrm{m})$ in a 2D layout.

Picture of wood samples, after sanding, taken by an electron microscope, show different and complex shapes of particles of wood dust (Figure 7). As described in the Particle Atlas [67], the diverse geometric expression could be observed, such as cylinders, cones, rectangular prisms, and spheres [60].

Mazzoli et al. [60] provided microscope analyses of dusts from two hardwoods (sessile oak, oak-tree), two tropical hardwoods (padouk, iroko), and three softwoods (pine, spruce, and larch). These were obtained using a grinding machine with 360-grit sanding paper.

Gómez Yepes and Cremades [61] analyzed the particle characteristics in Quindio (size distributions, aerodynamic equivalent diameter $(D a)$, elemental composition, and shape factors), and particles were then characterized via scanning electron microscopy (SEM) in conjunction with energy dispersive $X$-ray analysis. Results from their analysis of particulate matter showed that the cone-shaped particle ranged from 2.09 to $48.79 \mu \mathrm{m} D a$; the rectangular prism-shaped particle from 2.47 to $72.9 \mu \mathrm{m} D a$; the cylindrically-shaped particle from 2.5 to $48.79 \mu \mathrm{m} \mathrm{Da}$; and the spherically-shaped particle from 2.61 to $51.93 \mu \mathrm{m} D a$.

Oak dust provides a similar comparison with marblewood dust, as oak is the hardest Slovak wood. In all investigated oak fractions, the isometric shape of particles with sharp edges and rounded corners, which is more typical for fraction $<100 \mu \mathrm{m}[3]$. 


\subsection{Ignition Temperature of Airborne Dust}

Vandličkova et al. [29] studied the processes of ignition within airborne wood dusts. They [29] studied the specificities of the dust ignition process in different stages. The first stage is the beginning of an explosion: The dust was sprinkled into a ceramic tube furnace, with dust carbon residue. In the second stage, the unburned wood dust was ignited with the most incredibly intense flame. Subsequently, in the third state, flame slowly diminished with side effects.

The ebony dust of $500 \mu \mathrm{m}, 315 \mu \mathrm{m}$, and $71 \mu \mathrm{m}$ fractions were obtained the maximum flame (Figure 8). It was noted that when using larger particles, the flame had a lower intensity.

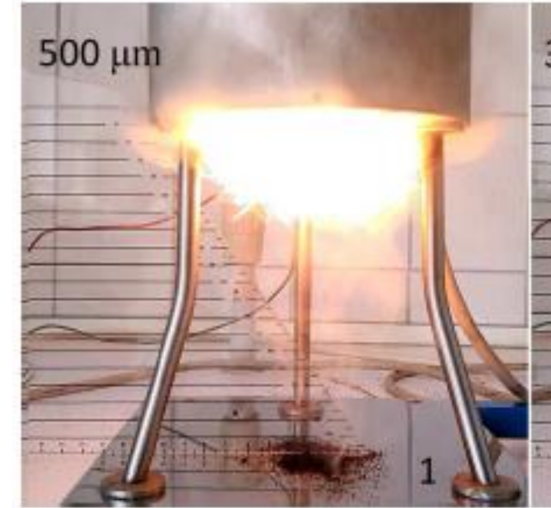

(a)

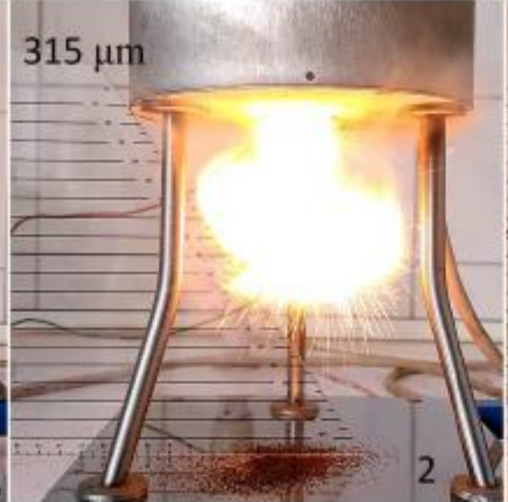

(b)

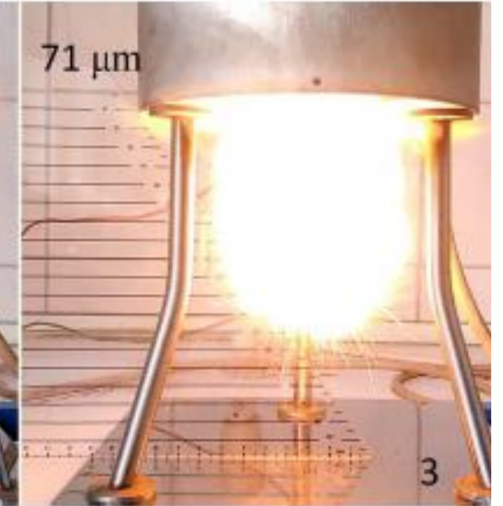

(c)

Figure 8. The flame on ignition (conditions: $0.2 \mathrm{~g}$ of dust, air pressure of $30 \mathrm{kPa}$, the temperature of the ceramic tube furnace $500{ }^{\circ} \mathrm{C}$ ). Images were prepared using a Basler a602fc-2 high-speed camera (Basler AG, Ahrensburg, Germany). Legend: (a) Point of ignition for fraction $500 \mu \mathrm{m}$ of ebony dust; (b) point of ignition for fraction $315 \mu \mathrm{m}$ of ebony dust; (c) point of ignition for fraction $71 \mu \mathrm{m}$ of ebony dust.

These results determined that the ignition temperature of airborne dust (Figure 9) showed a reduction in values relating to the smaller size fraction [68].

The minimum ignition temperature of cumaru for the $500 \mu \mathrm{m}$ fraction was $410{ }^{\circ} \mathrm{C}$, and this temperature decreased with changing particle size.

Particles of $100 \mu \mathrm{m}$ or less had the most significant effect on the change in the minimum temperature. The minimum ignition temperature of the ebony dust particles $500 \mu \mathrm{m}$, and $200 \mu \mathrm{m}$ was identical $\left(400{ }^{\circ} \mathrm{C}\right.$ ). The $100 \mu \mathrm{m}$ particle fraction had a minimum ignition temperature of $380{ }^{\circ} \mathrm{C}$. The last three size fractions had minimum ignition temperatures, due to strong dispersion in the heating furnace. An assumption was made applied to a larger dispersion of particles in a space for larger particles (of $500 \mu \mathrm{m})$, compared to $100 \mu \mathrm{m}$ with the same weight of the batch.

Marblewood had the highest tested minimum ignition temperatures of all samples. The minimum ignition temperatures started from $400{ }^{\circ} \mathrm{C}$ at a particle size of $500 \mu \mathrm{m}$ to $100 \mu \mathrm{m}$. Subsequently, the minimum ignition temperatures decreased with the particle size change to the level of $400{ }^{\circ} \mathrm{C}$, at a particle size of $63 \mu \mathrm{m}$.

Flame propagation behaviors and temperature characteristics of four types of biomass (poplar, pine, peanut, and corn sawdust particles) with two different particle sizes (50-70 $\mu \mathrm{m}$ and 100-200 $\mu \mathrm{m}$ ) distributions were studied experimentally by Jiang et al. [69]. The average flame propagation velocity and the amplitude of the velocity fluctuation are functions of the mass density of the biomass particles and depend on the particle size distributions [69].

Tropical woods came to a global market for their use in various products. Information about tropical wood fire parameters is poor. Fire parameters are not described in Safety Data Sheets [70,71]. Carrasco et al. [72] studied the heat transfer in Brazilian woods, using a sample that was thermally loaded to examine the potential for fire. Their results showed that there are curves of temperature on the time experiments that create the thickness $f$ chair layer corresponding with Carrasco's numerical models. 


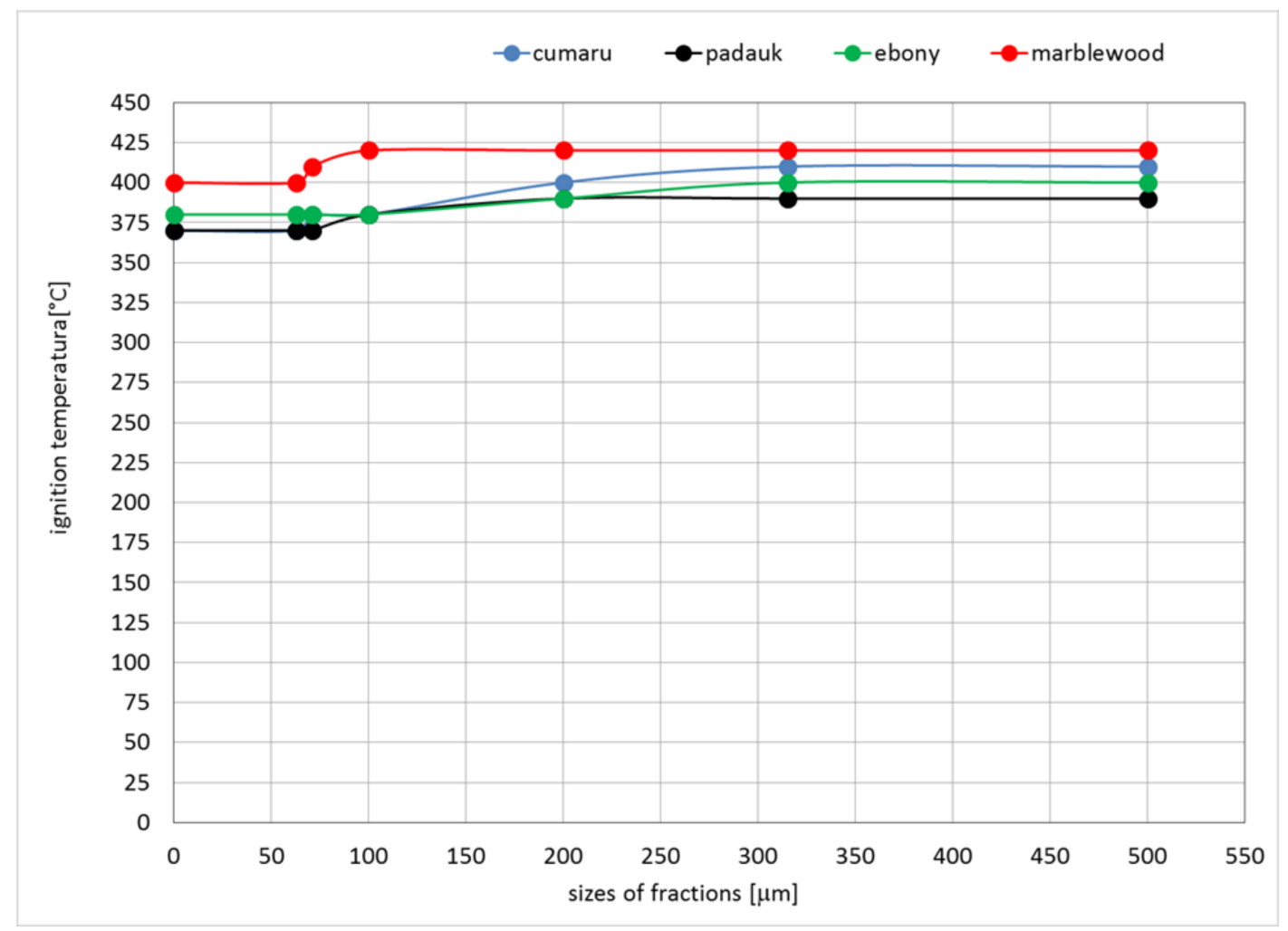

Figure 9. Ascertaining of the ignition temperature fractions of the tropical wood dusts.

\section{Conclusions}

From the perspective of this study, we can claim that we have obtained original results within the field of morphology of dust particles regarding the wood sanding process of tropical four species, as well as results concerning the determination of minimal ignition temperature airborne dust.

Our results show that fraction sizes of tropical wood dust are an important factor for fire ignition. However, the shape and morphology of tropical wood dust particles may also exert influence ignition process. All these aspects deserve to be studied further.

Marblewood has the highest minimum ignition temperature. Thermal stability can be found in its hardness and density.

Cumaru has specific behavior. It is a hardwood with a density comparable to marblewood, but the minimum initiation temperature decreases significantly with decreasing particle size (fraction $<63 \mu \mathrm{m}$ has a temperature of $370^{\circ} \mathrm{C}$ ).

The monitored dust particles retain their anatomical structure; the shapes of individual samples are different. These results offer different particle shapes such as: Rectangular prism-shaped particle, cylindrically-shaped particle and spherically-shaped particle.

Author Contributions: Conceptualization, M.V. and I.M.; methodology, investigation and resources S.G., J.S. and J.V.; writing—original draft preparation, I.M.; writing—review and editing V.M., L.M.O. and I.M. All authors have read and agreed to the published version of the manuscript.

Funding: This article was supported by the Cultural and Educational Grant Agency of the Ministry of Education, Science, Research and sport of the Slovak Republic on the basis of the project KEGA 0014UKF-4/2020 Innovative learning e-modules for safety in dual education.

Acknowledgments: This article was supported by the Project KEGA 0014UKF-4/2020 Innovative learning e-modules for safety in dual education.

Conflicts of Interest: The founding sponsors had no role in the design of the study, in the collection, analyses, or interpretation of data; in the writing of the manuscript and in the decision to publish the results. 


\section{References}

1. Top, Y. Relationship between Employees' Perception of Airborne Wood Dust and Ventilation Applications in Micro-Scale Enterprises Producing Furniture. BioRes 2020, 15, 1252-1264.

2. Očkajová, A.; Beljo Lučić, R.; Čavlović, A.; Tereňová, J. Reduction of dustiness in sawing wood by universal circular saw. Drv. Ind. 2006, 57, 119-126.

3. Ockajova, A.; Beljakova, A.; Luptakova, J. Selected properties of spruce dust generated from sanding operations. Drv. Ind. 2008, 59, 3-10.

4. Piernik, M.; Rogozinski, T.; Krauss, A.; Pinkowski, G. The influence of the thermal modification of pine (Pinus sylvestris L.) wood on the creation of fine dust particles in plane milling Fine dust creation in the plane milling of thermally modified pine wood. J. Occup. Health 2019, 61, 481-488. [CrossRef] [PubMed]

5. Očkajová, A.; Kučerka, M.; Kminiak, R.; Krišt'ák, L.; Igaz, R.; Réh, R. Occupational Exposure to Dust Produced When Milling Thermally Modified Wood. Int. J. Environ. Res. Public Health 2020, 17, 1478. [CrossRef] [PubMed]

6. Očkajová, A.; Barcík, Š.; Kučerka, M.; Koleda, P.; Korčok, M.; Vyhnáliková, Z. Wood dust granular analysis in the sanding process of thermally modified wood versus its density. BioRes 2019, 14, 8559-8572.

7. Igaz, R.; Kminiak, R.; Kristak, L.; Nemec, M.; Gergel, T. Methodology of Temperature Monitoring in the Process of CNC Machining of Solid Wood. Sustainability 2019, 11, 95. [CrossRef]

8. Li, H.T.; Chen, X.K.; Deng, J.; Shu, C.M.; Kuo, C.H.; Yu, Y.C.; Hu, X.Y. CFD analysis and experimental study on the effect of oxygen level, particle size, and dust concentration on the flame evolution characteristics and explosion severity of cornstarch dust cloud deflagration in a spherical chamber. Powder Technol. 2020, 372, 585-599. [CrossRef]

9. Huang, C.; Chen, X.; Yuan, B.; Zhang, H.; Shang, S.; Zhao, Q.; Dai, H.; He, S.; Zhang, Y.; Niu, Y. Insight into suppression performance and mechanisms of ultrafine powders on wood dust deflagration under equivalent concentration. J. Hazard. Mater. 2020, 394, 122584. [CrossRef]

10. Demers, P.A.; Weinrich, A.J. Wood Dusts. In Encyclopedia of Toxicology, 3th ed.; Elsevier: New York, NY, USA, 2014; pp. 981-983.

11. Guo, L.; Xiao, Q.P.; Zhu, N.F.; Wang, Y.; Chen, X.L.; Xu, C.Y. Comparative Studies on the Explosion Severity of Different Wood Dusts from Fiberboard Production. BioRes 2019, 14, 3182-3199.

12. Rogoziński, T.; Wilkowski, J.; Górski, J.; Czarniak, P.; Podziewski, P.; Szymanowski, K. Dust creation in CNC drilling of wood composites. BioRes 2015, 10, 3657-3665. [CrossRef]

13. Liu, A.H.; Chen, J.Y.; Huang, X.F.; Lin, J.J.; Zhang, X.C.; Xu, W.B. Explosion parameters and combustion kinetics of biomass dust. Bioresour. Technol. 2019, 294, 122168. [CrossRef] [PubMed]

14. Gaspercova, S.; Osvaldova Makovicka, L. Fire protection in various types of wooden structures. Civ. Environ. Eng. 2015, 11, 51-57. [CrossRef]

15. Kamal, A.; Malik, N.R.; Martellini, T.; Cincinelli, A. Source, profile, and carcinogenic risk assessment for cohorts occupationally exposed to dust-bound PAHs in Lahore and Rawalpindi cities (Punjab province, Pakistan). Environ. Sci. Pollut. Res. 2015, 22, 10580-10591. [CrossRef]

16. Ojima, J. Generation rate and particle size distribution of wood dust by handheld sanding operation. J. Occup. Health 2016, 58, 640-643. [CrossRef]

17. Mračková, E.; Tureková, I. The dimensional characteristics of the particles of wood dust of selected deciduous trees considering to explosion. Key Eng. Mater. 2016, 688, 182-189. [CrossRef]

18. Nasir, V.; Cool, J. A review on wood machining: Characterization, optimization, and monitoring of the sawing process. Wood Mater. Sci. Eng. 2020, 15, 1-16. [CrossRef]

19. Reinprecht, L.; Mamonova, M.; Panek, M.; Kacik, F. The impact of natural and artificial weathering on the visual, colour and structural changes of seven tropical woods. Eur. J. Wood Wood Prod. 2018, 76, 175-190. [CrossRef]

20. Panek, M.; Reinprecht, L. Effect of vegetable oils on the colour stability of four tropical woods during natural and artificial weathering. J. Wood Sci. 2016, 62, 74-84. [CrossRef]

21. Reinprecht, L.; Vidholdova, Z. Rot Resistance of Tropical Wood Species Affected by Water Leaching. BioRes 2019, 14, 8664-8677.

22. Vidholdova, Z.; Reinprecht, L. The Colour of Tropical Woods Influenced by Brown Rot. Forests 2019, 10, 322. [CrossRef] 
23. Reinprecht, L.; Vidholdova, Z.; Izdinsky, J. Bacterial and Mold Resistance of Selected Tropical Wood Species. Bioresources 2020, 15, 5198-5209.

24. Corassa, J.; Tiesen, C.; Dall'Oglio, O.; Melo, R. Durabilidade natural de dez madeiras amazônicas sob condicoes de campo. Nativa 2019, 7, 758. [CrossRef]

25. Imai, T.; Inoue, S.; Ohdaira, N.; Matsushita, Y.; Suzuki, R.; Sakurai, M.; Henriques De Jesus, J.; Ozaki, S.; Finger, Z.; Fukushima, K. Heartwood extractives from the Amazonian trees Dipteryx odorata, Hymenaea courbaril, and Astronium lecointei and their antioxidant activities. J. Wood Sci. 2008, 54, 470-475. [CrossRef]

26. Liu, Y.; Shao, L.; Gao, J.; Guo, H.; Chen, Y.; Cheng, Q.; Via, B.K. Surface photo-discoloration and degradation of dyed wood veneer exposed to different wavelengths of artificial light. Appl. Surf. Sci. 2015, 331, 353-361. [CrossRef]

27. Lacasta, A.M.; Haurie, L.; Monton, J.; Navarro Ezquerra, A.; Giraldo, P.; Sotomayor, J.; Palumbo, M. Characterization of the Fire Bbehavior of Tropical Wood Species for Use in the Construction Industry. In $A$ : World Conference on Timber Engineering. "WCTE 2016: World Conference on Timber Engineering, Vienna, Austria, 22-25 August 2016 Vienna, Austria: e-book"; Vienna Technischen Universität: Graz, Austria, 2016.

28. EN 50281-2-1: 2002. Electrical Apparatus for Use in the Presence of Combustible Dust. Part 2-1: Test Methods. Methods for Determining the Minimum Ignition Temperatures of Dust; European Committee for Standardization: Brussels, Belgium, 2002.

29. Vandličková, M.; Marková, I.; Osvaldová, L.M.; Gašpercová, S.; Svetlík, J. Evaluation of African padauk (Pterocarpus soyauxii) explosion dust. BioRes 2020, 15, 401-414.

30. Pereira, K.M.; Garcia, R.A.; do Nascimento, A.M. Surface roughness of Amazonian woods. Sci. For. 2018, 46, 347-356.

31. Stangerlin, D.M.; Cavalcante, C.F.P.; da Costa, C.A.; Pariz, E.; de Melo, R.R.; Dall'oglio, O.T. Mechanical properties of Amazonian woods estimated by ultrasound waves propagation methods. Nativa 2017, 5, 628-633.

32. De Oliveira Araújo, S.; Rocha Vital, B.; Oliveira, B.; Oliveira Carneiro, A.; Lourenço, A.; Pereira, H. Physical and mechanical properties of heat treated wood from Aspidosperma populifolium, dipteryx odorata and mimosa scabrella. Maderas. Cienc. Tecnol. 2016, 18. [CrossRef]

33. African Padauk. In the Wood Database. Available online: https://www.wood-database.com/african-padauk/ (accessed on 20 March 2020).

34. Ebony. In the Wood Database. Available online: https://www.wood-database.com/gaboon-ebony/ (accessed on 22 March 2020).

35. Book Group Author(s). IOP Conference Series: Earth and Environmental Science, Volume 126, Friendly City 4 'From Research to Implementation For Better Sustainability' 11-12 October 2017, Medan, Indonesia; IOP Publishing Ltd.: Bristol, UK, 2018; Volume 126.

36. Iringova, A.; Idunk, R. Assessment and usability of historic trusses in terms of fire protection-A case study. Int. Wood Prod. J. 2017, 8, 80-87. [CrossRef]

37. Mari, M.; Filippidis, G. Non-Linear Microscopy: A Well-Established Technique for Biological Applications towards Serving as a Diagnostic Tool for in situ Cultural Heritage Studies. Sustainability 2020, 12, 1409. [CrossRef]

38. Kirksey, S.; Helmreich, S. The emergence of multispecies ethnography. Cult. Anthropol. 2010, 25, 545-576. [CrossRef]

39. Marblewood. The Wood Database. Available online: https://www.wood-database.com/marblewood/ (accessed on 21 March 2020).

40. Vivek, V.; Vinod, K.; Sonthwal, K. Effect of Marble Dust Powder \& Wood Sawdust Ash on UCS and CBR Values of Soil. Int. J. Innov. Res. Sci. Eng. Technol. 2017, 17442-17446.

41. STN 49 0103: 1979. Wood. Determination of Moisture Content at Physical and Mechanical Testing; Slovak Technical Normalisation: Bratislava, Slovakia, 1979. (In Slovak)

42. ISO 23145-1:2007. Determination of Bulk Density of Ceramic Powders-Part 1: Tap Density; International Organization for Standardization: Geneva, Switzerland, 2007.

43. ISO 3310-1:201. Test Sieves-Technical Requirements and Testing_Part 1: Test Sieves of Metal Wire Cloth; International Organization for Standardization: Geneva, Switzerland, 2016. 
44. CEN Standard EN 13183-1: 2002. Workplace Atmospheres. Size Fraction Definitions for Measurement of Airborne Particles. Moisture Content of a Piece of Timber-Part 1: Determination by Oven Dry Method; European Committe for Standartion: Brussels, Belgium, 2002.

45. Goldsberry, A.; Hanke, C.W.; Countryman, N.B. A comparison of super wide field microscopy systems in Mohs surgery. J. Drugs Dermatol. 2014, 13, 1463-1465.

46. Poorter, L.; Rozendaal, D.; Bongers, F.; de Almeida-Cortez, J.S.; Zambrano, A.M.A.; Alvarez, F.S.; Andrade, J.L.; Villa, L.F.A.; Balvanera, P.; Becknell, J.M.; et al. Wet and dry tropical forests show opposite successional pathways in wood density but converge over time. Nat. Ecol. Evol. 2019, 3, 928-934. [CrossRef]

47. Stangerlin, D.M.; da Costa, A.F.; Goncalez, J.C.; Pastore, T.C.M.; Garlet, A. Monitoring of biodeterioration of three Amazonian wood species by the colorimetry technique. Acta Amaz. 2013, 43, 429-438. [CrossRef]

48. De Melo, B.A.; Molina-Rugama, A.J.; Leite, D.T.; de Godoy, M.S.; de Araujo, E.L. Bioactivity of powders from plant species on reproduction of Callosobruchus maculatus (FEBR. 1775) (Coleoptera: Bruchidae). Biosci. J. 2014, 30, 346-353.

49. Chipaia, F.D.; Reis, A.R.S.; Reis, L.P.; de Carvalho, J.C.; da Silva, E.F.R. Description anatomical macroscopic wood forest species of eigth market in the municipality of Altamira-PA, Brazil. J. Bioenergy Food Sci. 2015, 2, $18-24$.

50. Eleoterio, J.R.; da Silva, C.M.K. Comparision of dry kiln schedules for Cumaru (Dipteryx odorata), Jatoba (Hymenaea spp) and Muiracatiara (Astronium lecointei) obtained by different methods. Sci. For. 2012, 40, 537-545.

51. Soriano, J.; da Veiga, N.S.; Martins, I.Z. Wood density estimation using the sclerometric method. Eur. J. Wood Wood Prod. 2015, 73, 753-758. [CrossRef]

52. Marblewood, Wood Turning Pens. Available online: https://www.woodturningpens.com/marblewood/ (accessed on 21 April 2020).

53. King, D.A.; Davies, S.J.; Tan, S.; Nur Supardi, M.D.; Noor, R. The role of wood density and stem support costs in the growth and mortality of tropical trees. J. Ecol. 2006, 94, 670-680. [CrossRef]

54. Yuan, N.; Zhang, J.; Lu, J.; Liu, H.; Sun, P. Analysis of inhalable dust produced in manufacturing of wooden furniture. BioRes 2014, 9, 7257-7266. [CrossRef]

55. Ratnasingam, J.; Ramasamy, G.; Ioras, F.; Thanesegaran, G.; Mutthiah, N. Assessment of dust emission and working conditions in the bamboo and wooden furniture industries in Malaysia. BioRes 2016, 11, 1189-1201. [CrossRef]

56. Očkajová, A.; Marková, I. Particular size analysis of selected wood dust species particles generated in the wood working environment. Acta Univ. Matthiae Belii Ser. Environ. Manag. 2016, 18, 24-31. (In Slovak)

57. Očkajová, A.; Kučerka, M.; Krišták, L.; Igaz, R. Granulometric analysis of sanding dust from selected wood species. Bioresources 2018, 13, 7481-7495. [CrossRef]

58. ISO 9276-1:1998. Representation of Results of Particle Size Analysis—Part 1: Graphical Representation; International Organization for Standardization: Geneva, Switzerland, 1988.

59. Wolfrom, R.L. The Language of Particle size. As published in GXP. Spring 2011, 15, 2.

60. Mazzoli, A.; Favoni, O. Particle size, size distribution and morphological evaluation of airborne dust particles of diverse woods by Scanning Electron Microscopy and image processing program. Powder Technol. 2012, 225, 65-71. [CrossRef]

61. Gómez Yepes, M.E.; Cremades, L.V. Characterization of Wood Dust from Furniture by Scanning Electron Microscopy and Energy-dispersive X-ray Analysis. Ind. Health 2011, 49, 492-500. [CrossRef]

62. Dado, M.; Lamperova, A.; Kotek, L.; Hnilica, R. An evaluation of on-tool system for sanding dust collection: Pilot study. Manag. Syst. Prod. Eng. 2020, 28, 184-188. [CrossRef]

63. Sisler, J.D.; Mandler, W.K.; Shaffer, J.; Lee, T.; McKinney, W.G.; Battelli, L.A.; Orandle, M.S.; Thomas, T.A.; Castranova, V.C.; Qi, C.L. Toxicological assessment of dust from sanding micronized copper-treated lumber in vivo. J. Hazard. Mater. 2019, 373, 630-639. [CrossRef] [PubMed]

64. Dado, M.; Mikusova, L.; Schwarz, M.; Hnilica, R. Effect of selected factors on mass concentration of airborne dust during wood sanding. MM Sci. J. 2019, 2019, 3679-3682. [CrossRef]

65. Mamonova, M.; Reinprecht, L. The impact of natural and artificial weathering on the anatomy of selected tropical hardwoods. IAWA J. 2020, 41, 333-355. [CrossRef] 
66. Alfonso, V.A.; Carlquist, S.; Chimelo, J.P.; Rauber Coradin, V.T.; Détienne, P.; Grosser, D.; Ilic, J.; Wheeler, E.A.; Baas, P.; Gasson, P.E.; et al. IAWA list of microscopic features for hardwood identification with an appendix on non-anatomical information. IAWA Bull. 1989, 10, 219-232.

67. Stewart, I. The Particle Atlas Electronic Edition. Microsc. Today 1993, 1, 3. [CrossRef]

68. Calle, S.; Klaba, L.; Thomas, D.; Perrin, L.; Dufaud, O. Influence of the size distribution and concentration on wood dust explosion: Experiments and reaction modelling. Powder Technol. 2005, 157, 144-148. [CrossRef]

69. Jiang, H.P.; Bi, M.S.; Li, B.; Gan, B.; Gao, W. Combustion behaviors and temperature characteristics in pulverized biomass dust explosions. Renew. Energy 2018, 122, 45-54. [CrossRef]

70. Safety Data Sheet Cumaru. Available online: https://www.porta.com.au/wp-content/uploads/2019/03/PortaSDS-Cumaru-Hardwood-5303-90SDS.pdf (accessed on 20 April 2020).

71. Safety Data Sheet Cumaru. Available online: https://ropix.cirad.fr/FichiersComplementaires/-EN/Africa/ PADOUK.pdf (accessed on 30 April 2020).

72. Carrasco, E.V.M.; Caldas, R.B.; Oliveira, A.L.C.; Fakury, R.H. Numerical analysis of heat transfer in Brazilians wood species exposed to fire. Cerne. Lavras 2010, 16, 58-65.

Publisher's Note: MDPI stays neutral with regard to jurisdictional claims in published maps and institutional affiliations.

(C) 2020 by the authors. Licensee MDPI, Basel, Switzerland. This article is an open access article distributed under the terms and conditions of the Creative Commons Attribution (CC BY) license (http://creativecommons.org/licenses/by/4.0/). 